\title{
MODERN PHILOSOPHY OF HISTORY IN THE LIGHT OF A SYSTEMATIC APPROACH
}

\section{Dobrolyubska Yu. A.}

\section{INTRODUCTION}

The philosophy of history is based on the ability to see, understand, and explain the totality of history through abstract thinking in the form of philosophical reflection. Philosophical abstractions differ from the abstractions of other sciences in their versatility, reflectivity, ability to penetrate into the basis of things and phenomena of the world. They are, as M. Heidegger emphasized, "aimed at the whole, where man

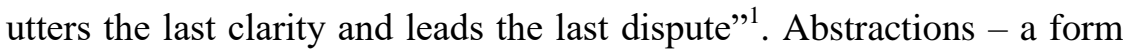
of being aware of the philosophy of history - are of different levels of generalization. The higher the level at which the philosopher reaches, the more abstract becomes the historical reality. Abstractions of the philosophy of history have many different forms of expression, often from the point of view of historical science are completely inadequate to the essence of the historical process and methodology of its knowledge. From the point of view of the philosophy of history, the Idea of History can be found in a wide variety of segments of objective (or subjective) reality, as well as in the field of mythological and esoteric knowledge. E. Eisenstadt proposes his own concept of axial time, which establishes a special kind of connection between the transcendental and terrestrial worlds, which requires the restructuring of the earthly order of things in accordance with the notions of the transcendental ${ }^{2}$. While respecting the

${ }^{1}$ Хайдеггер М. Основные понятия метафізики. Вопросы философии. 1989. № 9. С. 119.

2 Современные теории циивилизаций. Реферативный сборник. Москва: Просвещение, 1995. 348 с. 
rights of any one point of view, the philosophy of history does not endure, however, the absolutization of those rights. For example, a statement such as: "the fate of human society is a reflection of the fate of the human mind ... and only such a story can become the object of work and task for the philosopher" ; only "on the basis of theoretical history can and should build a philosophy of history that at least recognizes the principles of rational thinking and cognition", are dogmatic in many ways, claiming absoluteness and universality.

\section{Review of the Status of the Study of the Philosophy of History}

Obviously, for a philosophy that is predominantly implemented as a historical-critical paradigm of world reflection, implicitly incorporating the idea of variability of the world as an axiom, the idea that our reality is perhaps not the only one, that its veracity and reality are not guaranteed, is narrow. A rationalist approach is clearly insufficient. It destroys the inner balance of philosophical knowledge as a productive synthesis of mystical spiritual tradition and rationalism. We must talk about the specifics of rationality and its relationship with forms of extrinsic existence and cognition. In the philosophy of history, there are many different types of discourses, which is provoked by the methodological and substrate variability of philosophical knowledge, the presence of esotericism and exotericism. Due to the different views, one scientific discipline may contain more than one type of research. Quite often, the "underground" thoughts come to the forefront of ideas. Of course, not every point of view is equally worthy of attention and analysis. It is an inadmissibility to restrict and dogmatize philosophical reflection in general and philosophical and historical in particular. Different methodological and heuristic approaches can be applied to

${ }^{3}$ Стасюлевич М. М. Философия истории в главнейших ее системах. СПб.: типография М. М. Стасюлевича, 1902. С. 22.

4 Розов Н. С. Возможность теоретической истории: Ответ на вызов Карла Поппера. Вопросы философии. 1995. № 12. С. 62. 
philosophical and historical studies. The main thing then is not to leave semantic holes in the explanatory theory of the philosophy of history, to avoid inconsistencies in the application of those principles that were accepted as binding. To complain about the abstractness of philosophy is "the same as accusing the compilers of a medical atlas of forgetting the rules of decency. The question is only to what extent abstractions of philosophy are capable of clarifying the essence of a matter that gets into the orbit of philosophical reflection",

The philosophy of history is able not only to operate on abstract ideas about history and its knowledge, but also to reach the level of real historical research as far as is possible for fundamental humanitarian knowledge. Philosophical and historical research cannot consist of one abstraction. The philosopher of history must have some "historical feeling" in order for his understanding of the nature of the analyzed to be reflected rather than an external description of certain events. The philosopher of history inevitably uses the concepts of historical science, as well as concepts existing in the context of historical science. As K. Khvostova rightly points out, "the influence of modern philosophical currents ... on concrete historical research is indirect and implicit" ${ }^{\prime 6}$. The logical scheme of history must be filled with historical material, and in order to be empirically interpretable, the theoretical scheme must be meaningful and have a developed and branched categorical apparatus, that is, if necessary, to be specific. The imagination of the philosopher of history plays a significant role here.

Thus, the philosophy of history is bivalent: on the one hand, it is a speculative, conceptual construction of the ontology and epistemology of history, since without theoretical prerequisites no philosopher or historian can navigate the infinite variety of empirical material, he needs

5 Киссель М. А. Цивилизация как диалектическая проблема: Проблема цивилизации в философии Р. Дж. Коллингвуда. Цивилизации. Вып. 1. 1992. С. 45.

${ }^{6}$ Хвостова К. В. История: проблемы познания. Вопросы философии. 1997. № 4. C. 63. 
at least an initial hypothesis. Bivalence gives the philosophy of history a high productivity of research, although when referring to the bivalence of the philosophy of history, it should always be remembered that philosophical and historical knowledge is characterized by poor verifiability, so the second (empirical) side of the philosophy of history must be understood as a critical study.

A classic example of this kind is the philosophy of Hegel's history, which takes a consistent ascent from the heights of abstractions into an empire: the Spirit as a specific totality - the World Spirit (general) - the individual (single) - the spirit of the individual people (special and the subject of World history). At the same time, the philosophy of history does not strive for accurate historical truth. It is a philosophical truth that may not be accurate, but sufficient to man. Philosophy of history provides an opportunity to systematically understand, explain and present history from the point of view made beyond the limits of history, gives the opportunity to look at history through the eyes of a person other than the historical world and, as a result, receive not factual truth, but to explore the nature of conceptual connections of history from the standpoint a single Idea of history. We believe that this is the main activity that gives intellectual philosophy an intellectual justification.

To clarify the categorical apparatus of the study, let us try to define the object and object of the philosophy of history. The term "philosophy of history" was first used by Voltaire to understand critical or scientific history, the way of historical thinking when the historian thinks of history on his own, instead of repeating the stories of chroniclers. G. F. Hegel gave the term a different meaning: for him it meant universal or world history. The third meaning of the term can be found in the positivists: for them, the philosophy of history meant the discovery of general laws governing the movement of events that history must tell. 
R. J. Collingwood offers his own interpretation: "The philosophy of history examines not the past in itself and not the historian's view of it, but the first and second in their relationship"7.

In the modern philosophical and historical space, it is impossible to reveal the unity of views on the term. Y. Semenov defines the philosophy of history as the general theory of the historical process. The significance of this general theory, he sees, is that it is the most common method of penetrating the essence of historical phenomena ${ }^{8}$.

O. Panarin does not distinguish between philosophy of history and historiography at all, locating them through whom and defining this section of philosophy as intended to answer questions about the objective laws and spiritual meaning of the historical process, about ways of realizing human essential forces in history, about the possibilities of comprehending the universal ${ }^{9}$.

We consider it necessary to offer a definition of the subject and object of the philosophy of history. The object of science is the soughtafter segment of reality, what is being explored. A science object is less volatile than its subject.

The subject of any science is formed in the process of research and is determined a) cognitive attitude of a person to some relevant segment of reality, b) specific to this science means of cognition. Hence - the subject of science is mobile, open to innovation, but at the same time, stable as an invariant aspect of the content of science.

The subject of philosophy in general is the knowledge of the world at large and the knowledge of the mechanism of knowing man of this world. The fact of the fluidity of the subject of philosophy is well-

7 Коллингвуд Р. Дж. Идея истории. Автобиография. Москва: Наука, 1980. C. 6.

${ }^{8}$ Семенов Ю. И. Философия истории. Москва: Современные тетради, 2003. 776 c.

${ }^{9}$ Философия истории. Под ред. А. С. Панарина. Москва: Гардарики, 1999. 432 c. 
known and generally recognized. The degree of invariance of the subject of philosophy is also obvious: the aspect (s) of problems varies, depending on specific historical and cognitive situations, but the philosophical problems themselves are eternal. The object of philosophy is some totality, the boundaries of which are directly proportional to the essence of uniting into a single problematic field of things or phenomena.

We have assumed that the philosophy of history, as an independent philosophical discipline, obeys the philosophy, characteristic of philosophy, of the formation of its object and object, the unification of its categorical apparatus. Therefore, the subject of the philosophy of history is knowledge of the common, primordial origins and causes of world or any local history; knowledge of the meaning and fundamental, deterministic periodization and procedural form of the history of an idea; knowledge of the methodology of knowledge of history. The object of the philosophy of history is the totality of historical facts and patterns.

In the subject of any science distinguish its content and volume. The content of the subject of science is actually the sum of problems that are consistently solved at different stages of development of science. The volume of the subject of science is the sum of the aspects of the studied fragment of reality, that is, the sum of the analyzed aspects of the object of science.

The content of the subject of the philosophy of history is the mutually determinative and naturally changing processes of philosophical search. Namely search:

1) general philosophical and historical concepts and grounds that allow us to reflect on history in specific terms of stages and phases of historical development;

2) specific principles that substantiate the single structure of history; 
3) approaches to solving philosophical problems of necessity and causality in history;

4) specifics of philosophical, natural-scientific and proper historical analysis of history;

5) theories and methodologies of philosophical and historical knowledge of the world;

6) values in history and values of history itself;

7) social and psychological determinants of history;

8) the basics of interdisciplinary synthesis in the theory of philosophy of history;

9) constructing theoretical history as "a complex of interconnected theories that explain the course and interaction of many local histories and world history"10;

10) the origins and principles of the study of the specific language of history.

The volume of the subject of the philosophy of history is equal to the sum of the aspects of the object of scientific knowledge of the philosophy of history: ontological, epistemological, axiological - and natural variations of these aspects. A. Ignatov successfully differentiated the volume of the subject of the philosophy of history into the "what", "how", "where", "how much", "where" and "when" of history". In order to explain Ignatov's metaphors and clearly indicate the scope of the subject of the philosophy of history, we distinguish its main types. In our opinion, after Herder and Hegel, one of the most consistent, interesting, and successful attempts at a general typology of philosophy of history was the work of H. Rappoport, published in 1898. Rappoport went the following way: 1) identified two values of the philosophy of history - theoretical (scientific) and practical (applied); 2) distinguished

\footnotetext{
${ }^{10}$ Розов Н. С. Возможность теоретической истории. С. 66.

${ }^{11}$ Ignatov A. Anthropologische Geschichtsphilosophie: Für eine Philosophie der Geschichte in der Zeit der Postmoderne. Sankt Augustin: Akademia Verlag, 1993. $516 \mathrm{p}$.
} 
three directions of the philosophy of history - the providential (Augustine), the metaphysical (Hegel), the scientific (Vico - positivists Marx); 3) divided the scientific direction into physical, climatic, physiological, psychological and cultural-historical ${ }^{12}$. Within the science of the time, it was a typologization that to some extent streamlined philosophical and historical studies, which is why it, with the necessary transformations, lasted until almost the first third of the XX century.

Modern philosophical literature distinguishes materialistic, substantive, subjectivist types of philosophy of history (I. Kon, Y. Kimelev, B. Hubman). The reasons for this division are unclear. I. Kon distinguishes subjective and objective types of the philosophy of history on the epistemological principle. However, the resulting division is too broad and not entirely adequate to the task of accurately defining and typifying the philosophy of history. Equally insufficient is the division into linear and non-linear philosophical-historical concepts, given the extreme variability of the object of the philosophy of history, which clearly does not fit beyond the limits of spatial division and solely ontological consideration ${ }^{13}$.

Interesting is L. Goldstein's approach to this question. In "Historical Knowledge"14, he proposed to allocate in the theory of philosophy of history its infrastructure as the most important part in which the technique and methodology of history as a scientific discipline, and superstructure, that is, its own historical production, is explored. A. Rakitov proposed to divide historiography, historiosophy and historical epistemology so that the former belonged to the historical science, the latter to the philosophy of history, and

12 Раппопорт Х. Философия истории в ее главнейших течениях. СПб. : Павленков, 1898. С. 11.

${ }^{13}$ Губман Б. Л. Смысл истории: Очерки современных западных конщепций. Москва: Наука, 1991. 192 с.; Кимелев Ю. А. Философия истории. Современная западная философия. Словарь. Москва: ТОН-Острожье, 1998. С. 434-437.

14 Goldstein L. Historical Knowing. Austin: University of Texas Press, 1976. $242 \mathrm{p}$. 
historiosophy to them both. He distinguished the selected areas of knowledge by object, subject and type of knowledge, object and research methodology ${ }^{15}$. This approach, of course, is fruitful because it clearly delimits the fields of activity of the history sciences, but at the same time it "obscures" the peculiarity of philosophical and historical analysis of history, which is not limited only to the logical and methodological analysis of the historical, but also includes artistic and emotional cognitive stories. In addition, the term "historiosophy" is not clearly defined at all and is often understood (especially in the $n$ philosophical tradition) as an absolute synonym for the concept of philosophy of history.

A. Lubsky proposes a division into classical, non-classical, postmodern and neoclassical models of philosophical and historical knowledge ${ }^{16}$.

I. Boychenko distinguishes the classical, non-classical and postnon-classical paradigms of the philosophy of history. Within the framework of the latter, two main versions are distinguished: the topological one, founded by V. Kizima, and the monadological one, initiated in the works of I. Boychenk ${ }^{17}$. Postmodernist understanding of the philosophy of history is expressed in the idea of F. Ankersmith, according to which the philosophy of history is divided into three major areas: historiography, which describes the history of writing history; critical philosophy of history, which is a philosophical reflection on how historical conclusions are possible at all; a speculative philosophy of history that explores the rhythm of history ${ }^{18}$.

15 Ракитов А. И. Историческое познание: (Системно-гносеологический подход). Москва: Политиздат, 1982. С. 125-154.

16 Лубский А. В. Альтернативные модели исторического исследования. Москва: Изд-во «Социально-гуманитарные знания», 2004. 352 с.

${ }_{17}^{17}$ Бойченко І. В. Філософія історії. Київ: Знання, 2000. С. 321-343. 2007. 612 c.

18 Анкерсмит Ф. Р. Возвышенный исторический опыт. Москва: Европа, 


\section{Systems and Subsystems of the Philosophy of History}

Let's carry out the procedure of defining and typology of the philosophy of history by the systematic method as the most rigorous one available in the humanities today.

We emphasize that we understand philosophy as a special cognitive activity that, in equal parts, combines explanations and the system of its logical justification and understanding in the form of artistic-emotional and directly-intuitive achievement of truth. In doing so, we proceed from the fact that these aspects of cognitive activity intersect part of our volumes, being an explication and element of the general procedure of broad philosophical interpretation. The concept of "understanding" is borrowed from the theoretical and conceptual apparatus of hermeneutics, where it is interpreted as the result of the work of consciousness aimed at capturing meaning. Understanding in hermeneutics is the practical possession of senses. Today, humanitarian understanding is a universal category that characterizes activity with any semiotic system. Functions of understanding - cognitive, regulatory, ideological. Understanding is realized not only in a rational model, that is, as a universal conceptual thinking, theoretical activity, but also in non-verbal forms of human activity aimed at grasping meaning. Explanation is a universal way of theoretically treating the world as a world of objects, the sum of the means necessary to achieve a certain goal. The functions of explanation and understanding in science are the same, but unlike understanding of explanation, it is always implemented as a rational model of knowledge. The semantics of the explanatory paradigm is to answer the question: "why is this so?" And understanding - "what is it?". The explanatory paradigm is a narrower and more rigorous approach to object analysis, because in understanding events, the historian must simultaneously understand "the people of the past, understand what they are different from" ${ }^{\prime 19}$. However, explanatory

\footnotetext{
${ }^{19}$ Aron R. Lecons sur l'histoire. Paris: Éditions de Fallois, 1989. P. 92.
} 
and interpretative paradigms are closely linked in scientific research and often stimulate each other's development. "One-level explanations often prepare the ground for interpreting facts at a higher level" 20 . A deeper insight into the causes of events leads to a reinterpretation of the facts, which gives them new meaning and becomes the basis of a new explanation. The philosophy of history is characterized, as we have indicated above, by the same specific features.

We use the interpretation of the systematic approach in the version proposed by A. Uyemov, which is further developed by I. Dmitrevskaya ${ }^{21}$. Here, the essence of a systematic approach, as opposed to a non-systemic one, is understood as follows: a systematic approach is characterized by a particular direction of exploration from properties and relationships understood as a particular kind of thing to things themselves. For a non-systematic approach, the typical reverse direction of research is from things to properties and relationships.

In terms of defining the system, this means that the systematic approach involves a consistent study first of the concept of the system, then of its structure and, finally, of its elements. At the same time, the system itself is understood as a thing (or set of things) on which some relation with pre-fixed properties is realized. The concept of a system is a system-generating property $(\mathrm{P})$, a structure is a system-generating relation that forms a system $(\mathrm{R})$, a substrate is a thing or many things on which a system-generating relation, that is, a structure is performed. The substrate is the content component of the system. Adopting a systematic approach in the epistemology and methodology of science implies the orientation of the scientist to a particular type of structural ontology,

20 Вригт Г. Х., фон. Объяснение и понимание. Логико-философские исследования. Москва: Прогресс, 1986. С. 160-194.

21 Дмитревская И. В. Специфика философии как системы знания. Диалектика как методология научного познания. Иваново: издательство ИГУ, 1988. С. 20-31; Параметрическая общая теория систем и ее применения: сборник трудов, посвящ. 80-летию проф. А. И. Уемова. Одесса: Астропринт, 2008. 248 с. 
namely, to a qualitative understanding of things. Such an interpretation in the history of philosophy and science is related to the dialectical tradition, whereas metaphysical methodology is based on a spatial understanding of things.

Starting from the systematic definition of philosophy in general (concept - gaining knowledge about the ways and logic of being world and methods of knowing the ways and logic of being world; structure a certain type of philosophical reflection as a specific way of thinking, expressed in discrete concepts and knowledge; substrate - general) set the system of philosophy of history and the system of its various types.

In the formation of the system of philosophy of history, an indeterminate systemic component of knowledge, which fixes a problematic situation, is the concept - the system-forming property. His quest is related to incorporating it into the philosophy system and considering it as an aspect of the concept of the whole. In this case, the system of philosophy of history will be expressed by the formula $\mathrm{m}=$ $(\mathrm{S})=\mathrm{df}(\mathrm{R}(\mathrm{m})) \mathrm{P}$, where $\mathrm{m}$ (philosophy of history) is a system if and only if the properties of $\mathrm{P}$ (philosophical analysis of world and local history and ways of knowing it), which are in a pre-fixed relationship $\mathrm{R}$ (some type of philosophical reflection (method)), the substrate - a certain totality of historical facts and patterns, understood as historical reality itself or as text. Thus, the concept of the system of philosophy of history is $\mathrm{P}$ - certain properties of the philosophical method used here, the structure $\mathrm{R}$ - the method itself, the substrate $\mathrm{m}$ - those categories of history that result from the application of the method to a particular historical substance (historical events, text, etc.). So the philosophy of history as a system is the same philosophy, but "planted" on the historical substrate. For example, we define the system of philosophy of history as historical materialism. Here the concept will be the goal of any dialectical method - explaining development; structure - the laws of dialectics; substrate - historical knowledge that has been formed: socioeconomic formation, basis, superstructure, method of production. The 
same thing happens in any other philosophical and historical system: a certain domain (substance) $\mathrm{m} 1$ is denoted, a concept, structure is formed, and a substrate of the system $m$ appears - a transformed domain, that is, the knowledge that arose from the use of a certain method, therefore, a system, an integrity, appears. In our work, we apply this systematic method to an effective and theoretically sound typology of philosophical and historical knowledge. We want to show how and in the whole there is integrity in philosophical and historical constructions.

The system of philosophy of history, as well as the system of philosophy, is open and variant, ie capable of incorporating new knowledge either at the substrate level or at the level of structure or concept. Therefore, there is some "not entirely certainty" in the meaningful sense of the structure, substrate and concept of this system. This "not entirely certainty" gradually diminishes as new information in the content of not completely systematic components is filled with new information. In the course of this process, the system of philosophy of history acquires great meaningful accuracy and completeness. New information entering the system allows you to specify new subsystems. In our case, the formation of subsystems of different types of philosophy of history not only provides meaningful accuracy and completeness to the system of philosophy of history, but also illustrates the intersectional processes of differentiation and integration of philosophical knowledge.

It is possible to specify the ontological, epistemological and axiological subsystems of the philosophy of history. These subsystems perform in the system of philosophy of history the following functions: adaptation of the system to new knowledge, absorption of newly emerged knowledge, development, stabilization.

The ontological subsystem of the philosophy of history has as its concept the establishment of the essence, meaning and logic of being history as a fragment of objective (subjective) reality, that is, the creation of a general theory of history on the basis of a single explanatory principle; structure - ontological relation; substrate - the 
general plan and procedural form of the totality of the historical. The variability of the concept of the ontological subsystem of the philosophy of history provokes, in turn, the existence of its various subsystems: teleological, anthropological, eschatological, theological, worldsystemic, mental, globalist, environmental, civilizational, psycho-socioeconomic, cultural.

The epistemological subsystem of the philosophy of history has as its concept the knowledge of the laws and tendencies of the past, present and future historical; knowledge of possible heuristic principles of historical research; structure - epistemological relation; substrate - the cognitive "quality" of the totality of the historical. The variability of the concept and partly the structure of the epistemological subsystem of the philosophy of history provokes the existence of its various subsystems: positivist, phenomenological, analytical, speculative, normative, metaphysical, biological, divinatory, deconstructivist, postmodern.

The axiological subsystem of the philosophy of history has its concept of establishing the value of history and of history; structure the evaluation relation, the substrate - the ideal and due to the totality of the historical. The variability of the substrate of this subsystem of the philosophy of history makes it possible to distinguish the following subsystems: ethico-theological, ethical-teleological, reconstructive, ethical-political.

Each given subsystem of the philosophy of history contains aspects of other types of philosophy of history. For example, the ontological subsystem includes a number of aspects of the epistemological subsystem, the epistemological - a number of questions axiological and vice versa. A similar state of affairs is the result of the peculiarities of philosophical knowledge, in which ontological, epistemological and other aspects of the analysis of the general cannot have impenetrable boundaries with each other and coincide with a part of their volumes. We emphasize, moreover, that each of the distinguished subsystems of the philosophy of history, while retaining its 
essential affiliation with its system, realizes, first and foremost, its own dominant dominance in the study of history.

Each subsystem and subsystem realizes itself in specific philosophical and historical categories, adequate to the chosen philosophical method. For example, the philosophy of Hegel's history is realized through the categories of dialectics, through which the categories of spirit, reason, freedom are understood, and the philosophy of H. White's history is through categories of tropes, poetry, discourse, narrative. The "quality" of the philosophical and historical concepts created and the results of the analysis depend not only on the type but also on the level of philosophical reflection available to the researcher.

In order to specify the selected subsystems of the philosophy of history, let us consider them in several specific examples. The concepts we choose are at the same time one of the most significant, illustrative and least explored in the national historical and philosophical literature of variants of the ontological, epistemological and axiological subsystems of the philosophy of history.

One of the most popular ontological subsystems of the philosophy of history today is the non-classical mental subsystem of the philosophy of history, developed by the Annals school. The main purpose of the historical and philosophical and historical studies of the Annals is widely known - to create a picture of "total" history. This picture implies the widest possible coverage of all aspects of human life - from material and economic to cultural, political, anthropological. In this case, the totality of history for the Annals is not an eclectic description of all possible aspects of public life, but "a new study of the relationships between different sides of historical reality and especially the relationship between the material and ideal aspects of life"22.

22 Гуревич А. Я. От истории ментальностей к историческому синтезу. Споры о главном: Дискуссии о настоящем и будущем исторической науки вокруг франиузской Школье «Анналов». Москва: Институт всеобщей истории РАН, 1993. C. 16-29. 
According to the analysts, in the modern history and philosophy of history, the context in which the story of history is explored is important. The decisive context in solving the problems of philosophical and historical analysis is the consciousness and consciousness of man. It is interpreted as a mentality and is the main means of studying and reconstructing the historical picture of the world and the dynamics of social structures. Initially, the idea of mentality meant the existence of some form or style of thinking appropriate to a particular socio-historical situation (the "law of partisanship" of Levi-Bruhl, "composition of thinking" Bogdanov). Mark Block and Lucien Febre understood the mentality as a kind of analogue of the part of the collective unconscious that in Jung's deep psychology refers to the fundamentally unconscious. Today, the concept of "mentality" is interpreted by J. Revel, J. Le Goff, A. Burger and other analysts as some structural unity of images and representations of people, which defines their behavioral mechanism and cognitive landmarks in different historical eras. The mentality is regarded as a mediating link, a medium between the past and the present.

Another example of this intersection is the divinatory subsystem of the epistemological subsystem of the philosophy of history. The founder of the divinatory theory of the philosophy of history, V. Dilthey, answering the Kantian question "as a possible historical knowledge itself", identified as an axiom: only in the flow of psychic phenomena, teleologically related experiences, reveals a common correspondence characteristic of this historical era. History lies within the "inner experience", fundamentally different from the "outer" world of nature. The task of historical research is to identify goals and values as the main categories of history from the general flow of experiences, divinities, feelings, and empathy. T. Lessing agreed with Dilthey: the meaning in history must be introduced, otherwise the inevitable tragedy of the anthill. In the mid-twentieth century, the divinatory philosophy of history is dubbed psychohistory. 
"Objective well-being", "only feeling", "feeling" really provide the divinatory paradigm of the philosophy of history with the necessary heuristic, since it varies between the psychological and metaphysical domains. On the one hand, the sensation is universal in that it makes up the necessary coefficient of any sensual image, penetrates many mental relationships, through which people feel each other and unite in some social groups. Feeling does not belong to a variety of associations. The feeling of the queue of mental images engages in contemplation, and this connection is closer and more indissoluble than ordinary associations. It would be more correct to refer to it as "merger". Psychohistorians believe that a deep and repeated feeling of a situation is possible only if there is a natural connection between feeling and emotion, which is less characteristic of association as a more rational form, a form of pure intelligence. The connection of feeling and emotions is realized under the influence of the innate motives of the psychoanalytic subject, social conditions, personal practice, but all of this is connected primarily with the sphere of the unconscious psyche of the person and is called "direct emotional feeling". Here is the big role of imagination, fantasies, which at first glance are far from cold analysis, but which stimulate the researcher, mobilize him to realize the necessary activity, allow him to see the desired object (historical event, historical person), without trying to turn into this object. The philosopher of history formulates the appropriate situation and task of the study installation as the direct basis of the transformation and adjustment of the psyche of the analyst. Dilthey at one time required an active sensation, an experience of "all being" as is the case with an enthralled play or a fairy tale child, or a fascinated adult artwork. But the act of feeling does not occur so arbitrarily in historical research. The modern-day historianphilosopher, the philosopher of history formulates or activates the setting for the act of feeling, guided by discursive elements, scientific ways of analyzing objects that are unduly fascinating. 
In order to obtain objective information, a psychohistorian cannot accept an object of study, as it currently exists, to merge with it completely. In experiencing it, the psychohistorian sees a line that separates him from the object of experience-study. The experience comes and goes, and the installation that accompanies it remains. This setting in the psychoanalytic school is called a "complex", and it has an important influence on the flow of the sensation process, the formation of the necessary associative series. But, of course, such "complexes", despite their direct involvement in the conscious organization of psychoanalytic activity, may also be unconscious, and then they begin to "impose" their structure on the object or its fragment, which is the subject of analysis and relatively which they have updated. Then these "complexes" act as templates that distort the real state of things. Often, specific emotions and moods correspond to certain material structures. Just like a blanket thrown over a chair can be curled up and look sad and tired, so can historical events and their characters, psychoanalytically interpreted, take on a different meaning and quality than they really were. Therefore, often the result of feeling in psychohistory inadvertently acts as a predetermined one for itself. Such distortions are dictated by the peculiarities of the individual experience of the psycho-historian. Even with a high degree of professionalism, the researcher may not have enough internal experience to help animate and adequately understand the actions of historical persons of the past or the meaning of historical events of the past, such as, for example, some people do not understand the characters and actions of Shakespeare's heroes. Unconsciously impediment to the psychoanalytic interpretation of history may be the potentially stimulating images and the stereotypical systems of response in the dispositional blocks of the historian psychoanalyst's memory. Then the researcher will unconsciously adapt the resulting material to the "familiar" standard, sometimes created only by his imagination. 
With these things in mind, American historian D. Elton noted that while historians today are fascinated by Freud, psychologists at the same time are massively renouncing him. One of the first to formulate the motives of psychohistory U. Langer. In 1957, based on the conclusions of deep and dynamic psychology, he proposed his position as a historian. Its essence is as follows: historical research is the analysis of individual and collective unconscious people. However, psychohistory is not equal to the simple application of psychological explanations to the behavior of people taken in a historical context. This is nothing new. What is new is the use of psychoanalytic methodology, which extracts facts not from history but from the psyche of people, from the nature of their unconscious passions and trains, and with the help of these facts explains the events and meaning of history.

Langer focused his attention on the study of extreme human behavior in some historical situations: he analyzed the role of the mob and the mob in the French Revolution, the current totalitarian regimes, and the behavior of people during disease epidemics. T. Parsons and E. Erickson became prominent followers of Langer, and D. Demons, a student of the latter, published in 1994 a high-profile book "The Unreleased Prisoner: A Family History of Early America"23, in which he proves that the results of psychoanalytic study of history can be taught and as a historical narrative, not just as a "medical history" of society.

Modern psychohistorians believe that any political, historical, or social situation is always closely related to the personal situation of its main characters, and any social hierarchy is constructed and explained in terms and concepts of a particular sexual theory. "But the personal is always the peculiarities of one's character, mind-set, and how these peculiarities become political peculiarities - a question which cannot be answered in the psychoanalytic theory by simply translating the

${ }^{23}$ Demons J. The Unredeemed Captive: A Family Story from Early America. N. Y.: Vintage Books USA, 1994. 336 p. 
meanings of the relevant concepts from the field of conscious motivation into the realm of the unconscious," writes F. Weinstein ${ }^{24}$. Despite this objection, modern psychohistorians continue to argue that the methodology of history has always, at all times, been partly based on the results of research in psychological science, and the twentieth century has proved that psychoanalysis is inseparable from history and society. Therefore, for example, $\mathrm{H}$. Meyerhoff, psychoanalysis is not a branch of biology, medicine or psychology, but more a branch of history ${ }^{25}$.

In fact, the forms of historical explanations and methodological techniques of psychohistory are quite controversial. G. Himmelfarb rightly believes that psychohistorians extract facts not from history but from psychoanalysis of obscure objects from the point of view of history, so psychohistory, in his opinion, denies the basic criterion of historical proof - obviousness, ie logical indisputability and acceptance by all historians as well as the simplest and basic thesis of the historical method: to take into account in your analysis all, including negative, examples. Psychohistorians absolutize their method of "deep psychology" as the most adequate historical explanation, but it is suitable, according to Himmelfarb ${ }^{26}$, only to analyze one section of a person's real historical existence - unconscious intra-psychic conflicts. This brings the philosophy of history to a mechanistic approach to history in general, turns history into an epiphenomenon.

It should be noted that traditional history also uses moments of individual psychological research, weaving them into the fabric of narrative. But in psychohistory there is no narrative. Therefore, the divinatory moment may well be selectively used in the philosophy of

${ }^{24}$ Weinstein F. Psychohistory and the Crisis of the Social Sciences. History and Theory. 1995. Vol. 34. P. 305.

${ }^{25}$ Meyerhoff H. History and Philosophy: an Introduction. Philosophy of History in Our Time. New York: Doubleday Anchor Books, 1959. P. 20.

${ }^{26}$ Himmelfarb G. The New History and the Old. London: Belknap Harvard University Press, 1987. P. 165-168. 
history to characterize some one part of historical reality, to represent it or to refer to it. Psychohistory can organically enter traditional history as part of a larger historical interpretation. Particularly this is what L. Karsavin was referring to when he wrote that "the subject of history can in the shortest way be defined as the socio-psychic development of a single humanity"27. Divinatory or psychoanalytic history is a subsystem of the epistemological subsystem of the philosophy of history, since it has as its concept the knowledge of the historical special way of psychoanalytic research.

The postulates of the axiological subsystem of the philosophy of history were formulated by I. Kant, A. Schopenhauer, K. Bernheim, W. Windelband. The essence of these postulates is that history can only be explored and systematized by correlating it with any relevant value. G. Rickert understood values as primarily transcendental, objectified in cultural goods. This kind of installation was shared by M. Weber. E. Cassirer believed that the meaning of history can be understood only by learning to read the symbols of the universe as the highest values of humanity in general. For W. Windelband, values are first and foremost moral values. Almost the only work that compiles relevant views was written in 1912 by Yassen University professor A. Xenopol. Analyzing different perspectives on the problem, he came to the conclusion that the category of values in history and in the philosophy of history is farfetched. Value should, and in his opinion, be regarded only as an interest in being at all. Xenopoly put forward five arguments against the application of value to history: 1) the threat of subjectivity in the study of history; 2) value cannot create science and be a condition of truth. Only logic can do that. The historian is, of course, allowed to have his own scale of values, but it cannot be imposed on others because it exceeds his mission and competence; 3 ) any value, even moral, relative, and relativity can never serve as a scientific basis, axioms always have

\footnotetext{
${ }^{27}$ Карсавин Л. П. Философия истории. СПб. : АО Комплект, 1993. С. 98.
} 
absolute value; 4) value is often manifested by "unconscious" desire, not by reason, which undoubtedly destroys its methodological significance; 5) Values, as a rule, belong to the individual. They cannot be applied to the evolution of the human race at all. Values can only teach the history of the human spirit ${ }^{28}$. E. Loone argues in a similar vein and believes that the solution to the axiological problem lies beyond history ${ }^{29}$.

We emphasize that values can exist as personal, social ideals and as substantively embodied values. Personal values are similar to social values in that they can exist in the form of ideals, that is, models of the proper. But "if social values can and do not have any influence on human activity, then personal values are ideals that set the ultimate orientations of individual activity of a particular subject" ${ }^{\prime 30}$. If the field of personal values and the field of social values coincide, then, in large part, they can have an impact on the course and knowledge of the historical process. An example of such a coincidence is the concept of E. Trelch. In his works "On awakening the philosophy of history", "On the scope for judging historical objects and their relation to the cultural ideal of modernity", "The notion of historical development and universal history" Trelch substantiated the idea of two possible ways in the philosophy of history: formal historical logic and meaningful construction historical process. He understood them "as two separate and logically isolated problems that have a separate effect and meaning" 31 . In formal historical logic Trelch identified, as the main, the category of individual historical totality of individual historical events.

28 Ксенополь А. Д. Понятие «иенности» в истории. Киев: Типография Т. Г. Мейнандера, 1912. С. 21-23.

29 Лооне Э. Н. Современная философия истории. Таллин: Ээсти раамат, 1980. C. 95 .

30 Леонтьев Д. А. Ценность как междисциплинарное понятие: Опыт многомерной реконструкции. Вопросы философии. 1996. № 4. С. 24.

${ }^{31}$ Трельч Э. Историзм и его проблемы. Логическая проблема философии истории. Москва: Юрист, 1994. 719 с. 
Trelch understood it as a combination of factual (given by nature and circumstances) and proper, ideal.

The latter is indeed extremely important because it limits the possibility of subjectivism in the understanding of historical events. From the marked fundamental category Trelch deduces all others: eternity and disposability, the unconscious, creative, freedom, development. The rules of withdrawal of these categories are not specifically stated, but this is the idea of Trelch: historical logic must seamlessly pass into the meaningful construction of the historical process. Trelch called this construction a universal or material philosophy of history. The subject matter of the material philosophy of history is constituted by the acceptance as the dominant definite historical totality. The problematic field of the material philosophy of history is defined by the following chain: the duty - the relation to it the understanding of one's own individual and historical state - the idea of shaping the future - the need to take an "actual" position in specific assessments of history. The idea of obligation and teleology of individual and divine will, capable of shaping the future, prevails in the philosophy of Trelch's history. According to Trelch, the metaphysics of will and obligation is the only solution to the problem in the field of philosophy of history. The meaning of this metaphysics is to show the true unity of history.

According to Trelch, the material philosophy of history occupies an intermediate position between empirical history and ethics and has a virtually ethical purpose, in which it is easy to see Kantian motives. The objectives of the material philosophy of history Trelch considered gaining scale to measure the past, present and future and create a new cultural synthesis. This scale is first determined by the category of individual totality, so it is obtained through the measurement of each historical formation in accordance with its individual ideals and capabilities and with due consideration for its inclusion in the context of historical and universal significance. The scale found must be forward 
looking and, accordingly, have different meanings. The scale can be made in the first degree (for other people's totality) and in the second (for the modern historical era). But the main thing is not that. The scale of history, according to Trelch, must be both objective (living immersion in history) and a priori. Priority Trelch understands as a "simple fact of life", a spontaneous force of spirit and will. Trelch considers such an interpretation of a priori "properly understood", ie free from accusations of "timeliness" and "eternity." Together, the a priori and objectivity of the scale sought to solve the main, according to Trelch, the task of history is to realize the higher purpose of historical thinking and historical creativity - to create a cultural synthesis of the present. This synthesis "must shape the present and the future from scientific and historical interpretations of the past" ${ }^{\prime 32}$. The cultural synthesis of modernity is defined in its fundamentals as a category of individual totality, so it is always historically individual and, in the selection of facts, is only a prerequisite and ideal of the general history, not its prototype.

According to Trelch, the task of the philosophy of history is to stimulate an ethical will to act on the basis of a value approach. Of the two possible axiological approaches to the philosophy of history absolutist (the existence of values is confirmed in itself) and relational (values exist through man) - Trelch obviously implements the second. He greatly developed the theory of the philosophy of history, introducing categories of historical scale and cultural synthesis, understood as the realization of axiological ideas.

Axiological subsystems of the philosophy of history, similar to the one outlined, where the concept becomes the study of the values of history and the metaphysics of duty, not uncommon in the philosophy of history. These topics were the subject of ethical and theological reflection on the philosophy of the history of Augustine, Voltaire,

32 Трельч Э. Историзм и его проблемы. С. 193. 
McTaggart, T. de Chardin. Therefore, to say that axiology is generally irrelevant to the philosophy of history is wrong. Another thing is that, as in the case of the previous subsystems of the philosophy of history, the axiological subsystem is closely intertwined with ontology and epistemology, and requires the careful efforts of the researcher to extract the dominant axiological element of the construction of the subsystem.

\section{CONCLUSIONS}

Characterization of the philosophy of history as a separate philosophical discipline, the abstractions of the philosophy of history at different levels of generalization, the author's definition of the object and object of the philosophy of history, the attempt to analyze the philosophy of history from the standpoint of a systematic approach.

Philosophy of history is a separate philosophical discipline that obeys the philosophy of understanding the rules of understanding the world. Abstractions of the philosophy of history are of different levels of generalization: the higher the level of philosophical reflection on which the researcher goes, the more abstract the historical reality becomes. Abstractions of the philosophy of history come in many forms of expression: to seek the idea of history, while observing the absolute rigor of explanatory theory can be in any segment of objective or subjective reality, in the field of mythological or esoteric knowledge. The philosophy of history is bivalent: it is a conceptual construction of the ontology, epistemology and axiology of history and, at the same time, an empirical generalization of the data of other sciences. The object of the philosophy of history is the totality of historical facts and patterns. The subject of the philosophy of history is knowledge of the general, primordial origins and causes of world or any local history; knowledge of the meaning, fundamental periodization and procedural form of history; knowledge of the methodology of knowledge of history; the content of the subject of philosophy of history are mutually determined processes of philosophical search, which naturally change 
from the general philosophical and historical concepts and grounds, which allow us to reflect on history in specific terms of stages and phases of historical development, to the formation and study of specific language of history; the volume of the subject of philosophy of history is equal to the sum of aspects of the object of scientific knowledge of philosophy of history: ontological, epistemological, axiological - and variations of these aspects.

The philosophy of history is implemented in three subsystems ontological, epistemological, axiological, in which the variability of concept, structure and substrate provokes the existence of many of their subsystems. In this case, each given subsystem and subsystem of the philosophy of history primarily realizes its own dominant study of history, but contains aspects of other systems of philosophy of history.

\section{SUMMARY}

The system of history philosophy is open and variant, capable of incorporating new knowledge at the substrate, structure or concept level. Some "not entirely certainty" is retained in meaningful terms for the structure, substrate and concept of this system. It gradually decreases as new system components are filled with new information. During this process, the system of philosophy of history acquires meaningful accuracy and completeness. The formation of subsystems of different types of philosophy of history not only provides meaningful accuracy and completeness to the system of philosophy of history, but also illustrates the intersectional processes of differentiation and integration of philosophical knowledge.

It is substantiated that the philosophy of history is an independent philosophical discipline, which obeys the philosophy of understanding of the world, characteristic of philosophy. Abstractions of the philosophy of history are of different levels of generalization: the higher the level of philosophical reflection on which the researcher goes, the more abstract the historical reality becomes. However, abstractions of 
the philosophy of history come in different forms of expression: to seek the idea of history, while observing the absolute rigor of explanatory theory can be in any segment of objective or subjective reality, in the field of mythological or esoteric knowledge.

The object of the philosophy of history is the totality of historical facts and patterns. The subject of the philosophy of history is knowledge of the general, primordial origins and causes of world or any local history; knowledge of the meaning, fundamental periodization and procedural form of history; knowledge of the methodology of knowledge of history. The content of the subject of the philosophy of history are mutually determined processes of philosophical search, which naturally change from the general philosophical and historical concepts and grounds, which allow us to reflect on history in specific terms of stages and phases of historical development, to the formation and study of specific language of history.

The system of philosophy of history is divided into ontological, epistemological and axiological subsystems. These subsystems perform in the philosophy of history the function of adapting the system to new knowledge, absorption of newly emerged knowledge, development, stabilization. The ontological subsystem of the philosophy of history has as its concept the establishment of the essence, meaning and logic of being history as a fragment of objective (subjective) reality, that is, the creation of a general theory of history on the basis of a single explanatory principle; structure - ontological relation; substrate - the general plan and procedural form of the totality of the historical. The epistemological subsystem of the philosophy of history has as its concept the knowledge of the laws and tendencies of the past, present and future historical; knowledge of possible heuristic principles of historical research; structure - epistemological relation; substrate - the cognitive "quality" of the totality of the historical. The axiological subsystem of the philosophy of history has its concept of establishing the value of history and of history; structure - the evaluation relation, the 
substrate - the ideal and due to the totality of the historical. Each given subsystem of the philosophy of history contains aspects of other types of philosophy of history. Maintaining an inherent belonging to its system, each subsystem chooses a specific dominant in the study of history and realizes itself in particular philosophical and historical categories. The "quality" of the philosophical and historical concepts created and the results of the analysis depend not only on the type but also on the level of philosophical reflection available to the researcher.

\section{REFERENCES}

1. Хайдеггер М. Основные понятия метафізики. Bonpocbl философии. 1989. № 9. С. 116-122.

2. Современные теории цุивилизаций. Реферативный сборник. Москва: Просвещение, 1995. 348 с.

3. Стасюлевич М. М. Философия истории в главнейших ее системах. СПб.: типография М. М. Стасюлевича, 1902. 335 с.

4. Розов Н. С. Возможность теоретической истории: Ответ на вызов Карла Поппера. Вопросы философии. 1995. № 12. С. 55-69.

5. Киссель М. А. Цивилизация как диалектическая проблема: Проблема цивилизации в философии Р. Дж. Коллингвуда. Цивилизации. Вып. 1. 1992. С. 38-54.

6. Хвостова К. В. История: проблемы познания. Bonpocbl философии. 1997. № 4. С. 61-71.

7. Коллингвуд Р. Дж. Идея истории. Автобиография. Москва: Наука, 1980. 486 с.

8. Семенов Ю. И. Философия истории. Москва: Современные тетради, 2003. 776 с.

9. Философия истории. Под ред. А. С. Панарина. Москва: Гардарики, 1999. 432 с.

10. Ignatov A. Anthropologische Geschichtsphilosophie: Für eine Philosophie der Geschichte in der Zeit der Postmoderne. Sankt Augustin: Akademia Verlag, 1993. 516 p. 
11. Раппопорт Х. Философия истории в ее главнейших течениях. СПб. : Павленков, 1898. 180 с.

12. Губман Б. Л. Смысл истории: Очерки современных западных конщепиий. Москва: Наука, 1991. 192 с.

13. Кимелев Ю. А. Философия истории. Современная западная философия. Словарь. Москва: ТОН-Острожье, 1998. C. 434-437.

14. Goldstein L. Historical Knowing. Austin: University of Texas Press, 1976. 242 p.

15. Ракитов А. И. Историческое познание: (Системногносеологический подход). Москва: Политиздат, 1982. 303 с.

16. Лубский А. В. Альтернативные модели исторического исследования. Москва: Изд-во «Социально-гуманитарные знания», 2004. $352 \mathrm{c}$.

17. Бойченко І. В. Філософія історії. Київ: Знання, 2000. $723 \mathrm{c}$.

18. Анкерсмит Ф. Р. Возвышенный исторический опыт. Москва: Европа, 2007. 612 c.

19. Aron R. Lecons sur l'histoire. Paris: Éditions de Fallois, 1989. $292 \mathrm{p}$.

20. Вригт Г. Х., фон. Объяснение и понимание. Логикофилософские исследования. Москва: Прогресс, 1986. С. 160-194.

21. Дмитревская И. В. Специфика философии как системы знания. Диалектика как методология научного познания. Иваново: издательство ИГУ, 1988. С. 20-31.

22. Параметрическая общая теория систем и ее применения: сборник трудов, посвящ. 80-летию проф. А. И. Уемова. Одесса: Астропринт, 2008. 248 с.

23. Гуревич А. Я. От истории ментальностей к историческому синтезу. Споры о главном: Дискуссии о настоящем и будущем исторической науки вокруг франиузской Школь «Анналов». Москва: Институт всеобщей истории РАН, 1993. С. 16-29. 
24. Demons J. The Unredeemed Captive: A Family Story from Early America. N. Y.: Vintage Books USA, 1994. 336 p.

25. Weinstein F. Psychohistory and the Crisis of the Social Sciences. History and Theory. 1995. Vol. 34. P. 299-319.

26. Meyerhoff H. History and Philosophy: an Introduction. Philosophy of History in Our Time. New York : Doubleday Anchor Books, 1959. P. 5-24.

27. Himmelfarb G. The New History and the Old. London: Belknap Harvard University Press, 1987. 188 p.

28. Карсавин Л. П. Философия истории. СПб. : АО Комплект, 1993. $351 \mathrm{c}$.

29. Ксенополь А. Д. Понятие «ценности» в истории. Киев: Типография Т. Г. Мейнандера, 1912. $52 \mathrm{c}$.

30. Лооне Э. Н. Современная философия истории. Таллин: Ээсти раамат, 1980. $293 \mathrm{c}$.

31. Леонтьев Д. А. Ценность как междисциплинарное понятие: Опыт многомерной реконструкции. Вопросы философии. 1996. № 4. C. 4-36.

32. Трельч Э. Историзм и его проблемы. Логическая проблема философии истории. Москва: Юрист, 1994. 719 с.

\section{Information about the author: Dobrolyubska Yu. A.,}

Doctor of Philosophical Sciences, Professor, Head of the Department of World History and Methodology of Science, South Ukrainian National Pedagogical University named after K. D. Ushinsky 26, Staroportofrankivska str., Odesa, 65020, Ukraine 